\title{
MANIFESTATION OF EMBRYOGENIC POTENTIAL IN CULTURE OF ZYGOTIC EMBRYOS OF QUERCUS ROBUR L.
}

\author{
MÁRIA Gabriela OSTROLUCKÁ, DiAna KrajMEROVÁ \\ Institute of Plant Genetics, \\ Slovak Academy of Sciences, \\ Akademická 2, P.O. Box 39A, 95007 Nitra, Slovak Republic
}

\begin{abstract}
For the initiation of somatic embryogenesis early cotyledonary stage of zygotic embryo explants (from 15 th July until late August) was suitable. The highest frequency of differentiation of somatic embryos was obtained on cotyledons of zygotic embryos cultured on basal modified medium MS (with 1/2 concentration macronutrients) or WPM medium containing 500 mg. $1^{-1}$ glutamine, proline and casein hydrolysate and supplemented with 2,4-D (1,0-2,0 mg. $\left.1^{-1}\right)$ and BAP $\left(0,5-1,0\right.$ mg. $\left.1^{-1}\right)$. The development of somatic embryos was direct and indirect and the process was continuous over a long period. Primary somatic embryos were able to produce secondary embryos. Repetitive somatic embryogenesis led to the proliferation of a large number of new somatic embryos on their cotyledons, hypocotyl or radicula. The process of embryo differentation is asynchronous - various stages of somatic embryos could be observed in embryogenic culture. A somatic embryo conversion was rare on tested media. Embryo germination occured on medium containing BAP $\left(0,1 \mathrm{mg} .1^{-1}\right)$ or on medium with ABA and $\mathrm{GA}_{3}$ (each $0,2 \mathrm{mg} . \mathrm{l}^{-1}$ ) after a previous culture on WPM medium without plant growth regulators supplemented with sorbitol (6\%). The embryo germination occurred also on WPM medium with $0.2 \mathrm{mg} \cdot 1^{-1}$ BAP when cultures were mantained at $2^{\circ} \mathrm{C}$ for 4 weeks. Only 8 somatic embryos developed into plantlets. Their transplantation to in vivo conditions was unsuccessful.
\end{abstract}

KEY WORDS: Quercus robur, immature embryos, somatic embryogenesis.

\section{INTRODUCTION}

In recent years some attempts have been made to induce somatic embryogenesis in several Quercus species (Gingas and Lineberger, 1989; Chalupa, 1990; Ostrolucká, Pret'ová, 1991; Manzanera, 1992; Manzanera et al. 1993) as an alternative approach for clonal propagation, especially for propagation of selected genotypes because reproduction of oaks by conventional techniques, such as grafting or cuttings, is usually not successful.

Experiment in our laboratory and also results of other authors proved that it is possible to obtain somatic embryos of Quercus sp. from immature zygotic embryo tissues.

This study brings the proof of embryogenic potential of immature zygotic embryos in Quercus robur L. This species is considered to be a recalcitrant species. Vegetative propagation is limited by low ability to root and generative propagation is limited by a low seed production.

\section{MATERIAL AND METHODS}

The acorns from open pollinated trees were collected in week intervals (July 15 to late August). Seeds were surface sterilized for $8 \mathrm{~min} 70 \%$ ethanol, rinsed in sterile distilled water and to sterilized in $0.1 \%$ solution of $\mathrm{HgCl}_{2} 15 \mathrm{~min}$. After ste- rilization seeds were three times rinsed in sterile distilled water. Complete embryos were extracted from seeds and placed on culture media. From embryos collected after 10th of August the embryonic axes with part of cotyledons were separated; larger cotyledons, were cut in the middle. These parts of embryos were cultured separately.

The basal culture medium was modified MS (Murashige and Skoog, 1962) with half concentration of macronutrients and 3\% (w/v) sucrose and WPM (Lloyd and McCown, 1980) with $2 \%(\mathrm{w} / \mathrm{v})$ sucrose. The basal media were supplemented with glutamine, proline and casein hydrolysate, $500 \mathrm{mg} . \mathrm{l}^{-1}$ each. Media containing cytokinin BAP $\left(0.5-1.0 \mathrm{mg} .1^{-1}\right)$ and auxins 2,4-D (1.0-2.0 mg. $\left.\mathrm{l}^{-1}\right)$, IBA (0.5-1.0 mg. $\left.\mathrm{.}^{-1}\right)$ and NAA (0.1-1.0 mg. $\left.\mathrm{l}^{-1}\right)$ were tested. WPM media with $0-1.0 \mathrm{mg} \cdot \mathrm{l}^{-1}$ BAP, combinations of ABA (0.1-1.0 mg.1-1 $)$ and $\mathrm{GA}_{3}(0.1-1.0$ mg. $\mathrm{l}^{-1}$ ) and hormone free WPM medium with $3-6 \%$ sorbitol were tested for the germination of somatic embryos. The media were solidified with $0.6 \%$ (w/v) Difco Bacto agar and adjusted to $\mathrm{pH} 5.7$ before autoclaving (at $120^{\circ} \mathrm{C}$ for $20 \mathrm{~min}$ ). Glutamine was filter sterilized. Cultures were kept at $25 \pm 1^{\circ} \mathrm{C}$ and $16 / 8$ hour photoperiod with light intensity $60 \mu \mathrm{E} \cdot \mathrm{m}^{-2} \cdot \mathrm{s}^{-1}$.

For histological study somatic embryos were fixed in FAA (70\% w/v ethanol: acetic acid: formalin 18:1:1), dehydrated in ethanol series, cleared in toluene and embedded in paraffin. Sections (10-13 $\mu \mathrm{m}$ thick) were stained with Ehrich haematoxylin. 

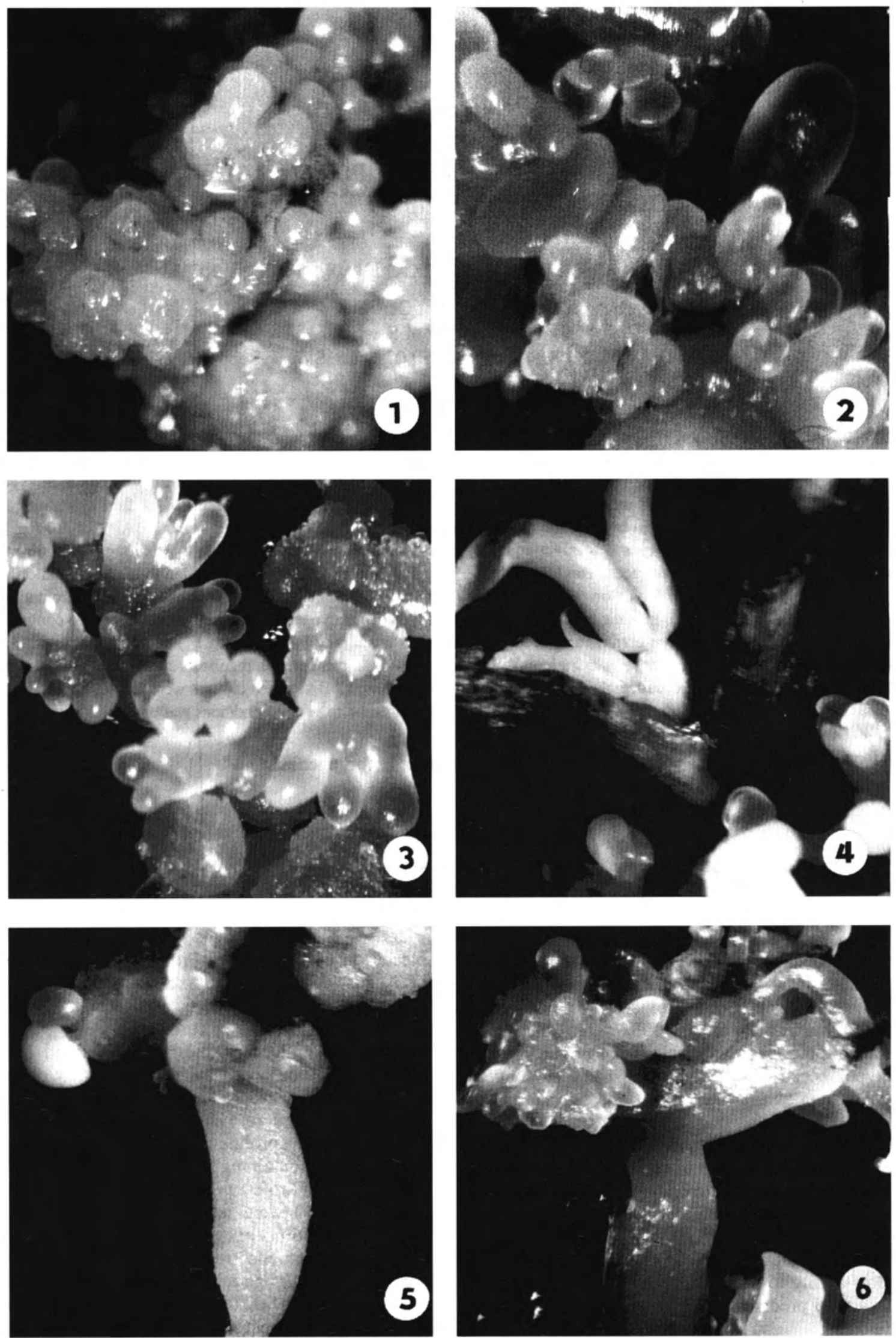

Figs 1-6. Fig. 1. Differentiation of globular structures on cotyledon segments of an immature embryo cultured on the WPM with 1.0 mg. $1^{-1}$ BAP and $1.0 \mathrm{mg} . \mathrm{I}^{-1} 2,4-\mathrm{D}$.

Fig. 2. Futher development of globular structures to torpedo-shaped somatic embryos.

Fig. 3. Numerous somatic embryos with various cotyledon number were formed on WPM medium with $1.0 \mathrm{mg} . \mathrm{l}^{-1} \mathrm{BAP}$ and $1.0 \mathrm{mg} . \mathrm{l}^{-1} 2,4-\mathrm{D}$. Fig. 4. Epicotyl emerging from between cotyledons of the germinating somatic embryo cultivated on WPM medium containing 0.2 mg. $\mathrm{I}^{-1} \mathrm{BAP}$ at $2^{\circ} \mathrm{C}$ for 4 weeks.

Fig. 5, 6. Repetitive occurrence of somatic embryogenesis. Adventive somatic embryos induced on the cotyledons of primary somatic embryos. 


\section{RESULTS AND DISCUSSION}

From tested culture media the modified MS medium and WPM medium containing $1.0 \mathrm{mg} . \mathrm{l}^{-1} \mathrm{BAP}$ and $1.0 \mathrm{mg} \cdot \mathrm{l}^{-1} 2,4-$ D or $2.0 \mathrm{mg} . \mathrm{l}^{-1}$ 2,4-D showed highest ability to stimulate differentiation of aggregates of globular structures (Fig. 1) directly on cotyledon segments of zygotic embryos of $Q$. robur after 8-10 weeks of cultivation. Paralelly, an embryogenic and non-embryonic calli were induced on some segments of zygotic embryos. Globular structures proliferated intensively and the frequency of their formation was increasing after regular transfer to fresh nutrient media containing 0.5-1.0 mg.1 $1^{-1}$ BAP and 1.0-2.0 mg.1 - $^{-1}$,4-D or media with $1.0 \mathrm{mg} .1^{-1}$ BAP and $1.0 \mathrm{mg} . \mathrm{l}^{-1}$ IBA. Globular structures developed through stages (Fig. 2 and Fig. 3) similar to those of zygotic embryo deve- lopment. In embryogenic culture various stages of somatic embryos occurred simultaneously. Structures on different stages of development originated directly from parental tissue. Not all globular structures passed through torpedo stage to cotyledonary stage. Some globular structures further produced colonies of globules on their surface.

Simultaneously, somatic embryos were formed indirectly via embryogenic callus and they further developed through stages that are identical to the process of direct somatic embryogenesis. The formation of somatic embryos was asynchronous. The non-embryogenic callus was incompact, vitreous without ability to differentiate somatic embryos. This type of callus gradually became necrotic.

Results of this experiment and of other authors (Gingas and Lineberger, 1989; Chalupa, 1990; Manzanera et al., 1992)
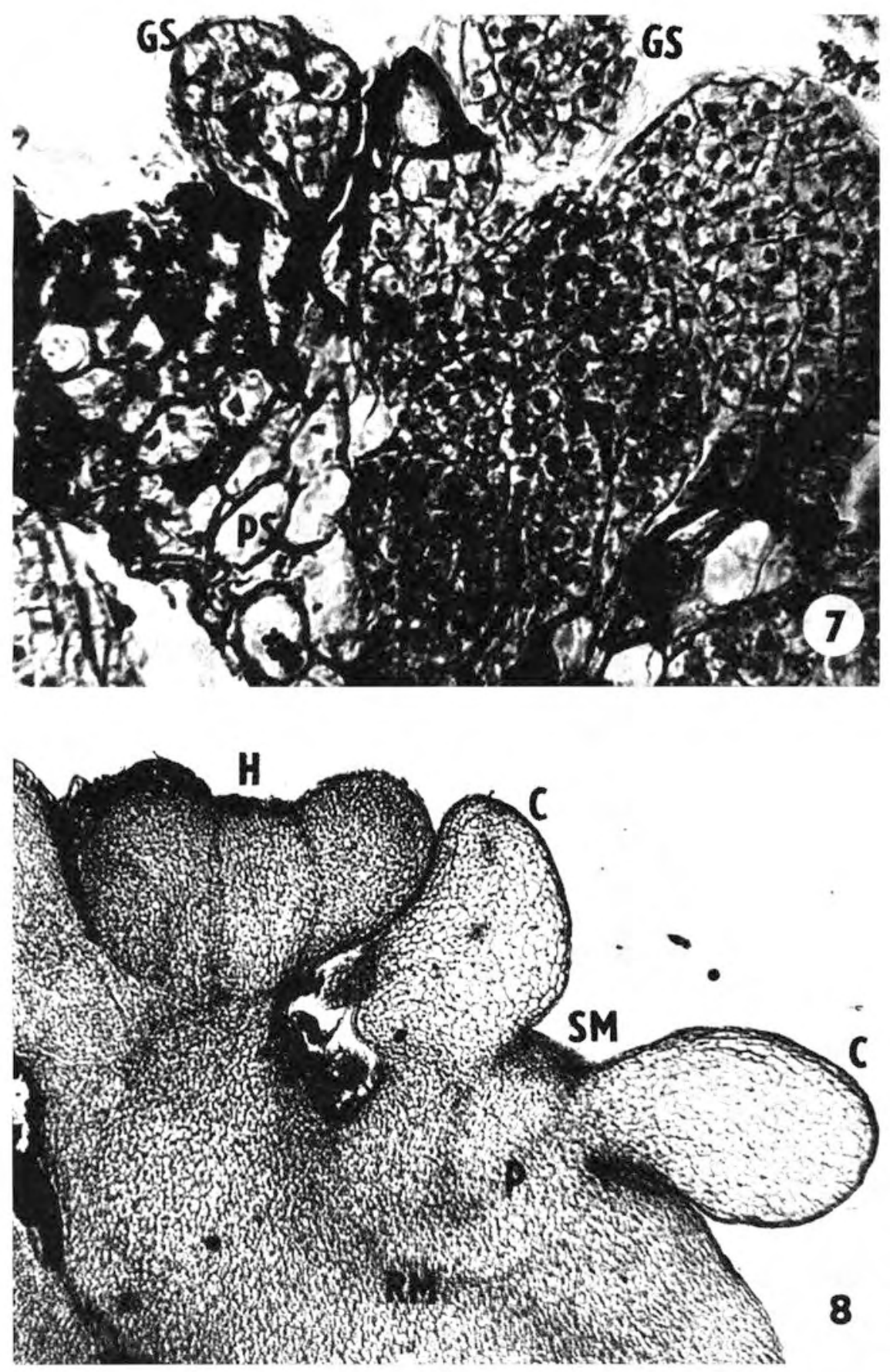

Fig. 7. Embryogenic culture consisted of vacuolated parenchymous cells (PC) and zones of "embryogenic" cells competent to differentiate multicellular globular structures (GS).

Fig. 8. Heart-shaped somatic embryo $(\mathrm{H})$ and early cotyledonary stage with two prominent cotyledons (C), shoot meristem (SM), root meristem (RM) and procambium (P). 
confirmed that it is possile to obtain a high number of somatic embryos on one explant. It is difficult to count somatic embryos in embryogenic masses. After various observation it can be said that immature embryos are highly competent to produce somatic embryos. The primary embryos cultivated on WPM medium containing BAP (1.0 mg. $\left.\mathrm{l}^{-1}\right)$ and 2,4-D (1.0 mg. $\left.\mathrm{l}^{-1}\right)$ showed the embryogenic potential for induction of adventive embryogenesis (Fig. 4 and Fig. 5) and had ability to develop in the process of continuous repetitive embryogenesis. The adventive embryos developed directly through globular stage on cotyledonary surface or radicular pole of primary embryos. We observed that induction of adventive embryos was increased after transfer of primary embryos to the medium with low concentration of BAP $\left(0.1 \mathrm{mg} . \mathrm{l}^{-1}\right)$ or hormone free medium for short period of time, approximately 30 days. The phenomenon of adventive embryogenesis was observed by Gingas and Lineberger (1989), Chalupa (1990), Kiss et al. (1992) and other. Kiss et al. (1992) reported that primary embryos are capable of embryogenesis in each of the different phases of embryogenesis. We have also observed this in our experiment.

The experiment showed that developmental stage of zygotic embryo and composition of culture media are important factors affecting embryogenic potential. The embryogenic response on modified MS and WPM media with the same growth regulators content were similar, thus we suppose that composition of basal media doesn't have the great effect on the process of somatic embryogenesis. For the initiation of the somatic embryogenesis the early cotyledonary stage appeared to be suitable (from 15 th July and early August).

According to the authors mentioned above, cytokinin BAP combined with auxins 2,4-D, IBA or NAA had favourable effect on the initiation of somatic embryogenesis. Only Chalupa (1990) reported that 2,4-D was inefficient. Other authors came to conclusion that 2,4-D plays an important role in cell division and affects the embryogenic potential.

The germination of mature somatic embryos still remains to be a problem in experiments. All authors reported a low germination ability of somatic embryos and viable plantlets were not obtained or only in low frequency (Gingas and Lineberger, 1989; Chalupa, 1990; Manzanera et al., 1992). In our study, the somatic embryos conversion was rare. Embryo germination occurred on medium containing $0.1 \mathrm{mg} . \mathrm{l}^{-1} \mathrm{BAP}$ or on medium with $\mathrm{ABA}$ and $\mathrm{GA}_{3}\left(0.2 \mathrm{mg} \cdot \mathrm{l}^{-1} \mathrm{each}\right)$ after previous culture on WPM hormone free medium supplemented with sorbitol $(6 \%)$. The germination was also observed on WPM medium with $0.2 \mathrm{mg} . \mathrm{l}^{-1} \mathrm{BAP}$ cultured at $2^{\circ} \mathrm{C}$ for 4 weeks (Fig. 6). Generally, the germination of somatic embryos was not effective in our experiment. Some embryos formed only roots and some formed only shoot apex. Only 8 somatic embryos developed into plantlets with epicotyl and primary roots. Their transplantation to the mixture of peat and perlite (1:1) was unsuccessful. Further experiments are required to improve this critical step and to achieve the plant regeneration.

Histological studies showed the cell differentiation in embryogenic culture that consisted of different types of cells large vacuolized parenchymatous cells and aggregates of "embryogenic" cells with prominent nuclei. Somatic embryos began to develop from "embryogenic" cells at the periphery zone where multicellular globular-shaped structures arose (Fig. 7). Fig. 8 illustrates the heart-shaped and early cotyledonary stages of somatic embryos, shoot and root apical meristems and procambium. Not all embrygenic structures developed to bipolar embryos but produced structures with various morphological abnormalities. The histological features of somatic embryogenesis in Quercus suber was reported by El Maataoui et al. (1990).

\section{LITERATURE CITED}

CHALUPA, V., 1990. Plant regeneration by somatic embryogenesis from cultured immature embryos of oak (Quercus robur L.) and linden (Tilia cordata Mill.). Plant Cell Reports 9: 398-401.

EL MAATAOUI, M., ESPAGNAC, H., MICHAUX-FERRIERE, N., 1990. Histology of callogenesis and somatic embryogenesis induced in stem fragments of cork oak (Quercus suber) cultured in vitro. Annals of Botany 66: 183-190.

GINGAS, V.O., LINEBERGER, R.D., 1989. Asexual embryogenesis and plant regeneration in Quercus. Plant Cell, Tissue and Organ culture 17: 191-203.

KISS, J., HEZSKY, L.E., KISS E., GYULAI, G., 1992. High efficiency adventive embryogenesis on somatic embryos of anther filament and immature proembryo origin inhorse-chesnut (Aesculus hippocastanum L.) tissue culture. Plant Cell, Tissue and Organ culture 30: 59-64.

LLOYD, G., McCOWN, B., 1980. Commercially feasible micropropagation of mountain laurel, Kalmia latifolia, by use of shoot tip culture. Combined Proc. International Plant Propagators Society 30: 421-427.

MANZANERA, J.A., 1992. Induccion de embriogenesis somatica en roble (Quercus robur L.). Investigacion Agraria, Sistemas y Recursos Forestales 1: 73-81.

MANZANERA, J.A., ASTORGA, R., BUENO, M.A., 1993. Somatic embryo induction and germination in Quercus suber L. Silvae Genetica 42: 2-3.

MURASHIGE, T. SKOOG, F., 1962. A revised medium for rapid growth and bioassays with tabacco tissue culture. Physiologia Plantarum 15: 473-497.

OSTROLUCKÁ, M.G., PRET’OVÁ, A., 1991. The occurence of somatic embryogenesis in the species Quercus cerris L. Biologia 46: 9-14. 


\section{POJAWIANIE SIĘ ZDOLNOŚCI EMBRIOGENNYCH W HODOWLI ZYGOTYCZNEGO ZARODKA QUERCUS ROBUR L.}

\section{STRESZCZENIE}

Somatyczna embriogeneza była inicjowana na zygotycznych zarodkach wyszczepionych w stadium wczesnych liścieni w czasie od połowy lipca do końca sierpnia. Najczęściej somatyczna embriogeneza zachodziła na liścieniach hodowanych na modyfikowanej pożywce MS z rozcieńczonymi do połowy makroelementami, oraz na pożywce VPM zawierającej $500 \mathrm{mg} . \mathrm{l}^{-1}$ glutaminy, proliny i hydrolizatu kazeiny z dodatkiem 2,4-D (1,0-2,0 mg. $\left.\mathrm{l}^{-1}\right)$ and BAP $\left(0,5-1,0 \mathrm{mg} \cdot \mathrm{l}^{-1}\right)$. Rozwój zarodków somatycznych zachodził bezpośrednio lub drogą pośrednią w dłuższym czasie. Pierwotne zarodki somatyczne mogły tworzyć liczne wtórne zarodki na liścieniach, hypokotylu i radykuli. Zarodki somatyczne różnicują się niesynchronicznie w hodowli obserwuje się więc liczne stadia. Kiełkowanie zarodków zachodziło na pożywce zawierającej BAP $\left(0.1 \mathrm{mg} . \mathrm{l}^{-1}\right)$ lub ABA i GA3 (obydwa $0,2 \mathrm{mg} . \mathrm{l}^{-1}$ ) gdy wcześniej były hodowane na VPM z $6 \%$ sorbitolu, lecz bez regulatorów wzrostu. Zarodki kiełkowały także na pożywce VPM z $0,2 \mathrm{mg} . \mathrm{l}^{-1}$ BAP gdy hodowle były przetrzymywane w $2^{\circ} \mathrm{C}$ przez 4 tygodnie. Uzyskano 8 sadzonek które jednak nie dały sie hodować w warunkach in vivo.

SŁOWA KLUCZOWE: Quercus robur, niedojrzałe zarodki, somatyczna embriogeneza. 